\title{
Comparison of the myocardial clearance of endothelial progenitor cells injected early versus late into reperfused or sustained occlusion myocardial infarction
}

\author{
Andrea J. Mitchell • Eric Sabondjian • Kimberley J. Blackwood • \\ Jane Sykes • Lela Deans • Qingping Feng • Robert Z. Stodilka • \\ Frank S. Prato • Gerald Wisenberg
}

Received: 10 March 2012/ Accepted: 15 June 2012/Published online: 27 June 2012

(C) The Author(s) 2012. This article is published with open access at Springerlink.com

\begin{abstract}
Stem cell transplantation following AMI has shown promise for the repair or reduction of the amount of myocardial injury. There is some evidence that these treatment effects appear to be directly correlated to cell residence time. This study aims to assess the effects of (a) the timing of stem cell injection following myocardial infarction, and (b) flow milieu, on cell residence times at the site of transplantation by comparing three time points (day of infarction, week 1 and week 4-5), and two models of acute myocardial infarction (sustained occlusion or reperfusion). Twenty-one dogs received 2 injections of 30 million endothelial progenitor cells. The first injections were administered by epicardial $(n=8)$ or endocardial injection $(n=13)$ either on the day of infarction $(n=15)$ or at 1 week $(n=6)$. The second injections were administered by only endocardial injection $(n=18) 4$ weeks
\end{abstract}

A. J. Mitchell · E. Sabondjian · K. J. Blackwood ·

R. Z. Stodilka · F. S. Prato

Department of Medical Biophysics,

The University of Western Ontario, London, ON, Canada

A. J. Mitchell - E. Sabondjian - K. J. Blackwood - J. Sykes · L. Deans - Q. Feng · R. Z. Stodilka · F. S. Prato - G. Wisenberg Lawson Health Research Institute, London, ON, Canada

Q. Feng

Departments of Medicine, Physiology, and Pharmacology,

The University of Western Ontario, London, ON, Canada

G. Wisenberg

Department of Medicine, The University of Western Ontario,

London, ON, Canada

G. Wisenberg $(\bowtie)$

London Health Sciences Centre, University Campus,

339 Windermere Road, London, ON N6A 5A5, Canada

e-mail: gerald.wisenberg@lawsonimaging.ca following the first injection. Cell clearance half-lives were comparable between early and late injections. However, transplants into sustained occlusion infarcts resulted in slower cell clearance $77.1 \pm 6.1(n=18)$ versus reperfused $59.4 \pm 2.9 \mathrm{~h}(\mathrm{n}=21) p=0.009$. Sustained occlusion infarcts had longer cell retention in comparison to reperfusion whereas the timing of injection did not affect clearance rates. If the potential for myocardial regeneration associated with cell transplantation is, at least in part, linked to cell residence times, then greater benefit may be observed with transplants into infarcts associated with persistent coronary artery occlusion.

Keywords Myocardial infarction - Stem cell therapy Residence time $\cdot$ Single photon emission computed tomography

\author{
Abbreviations \\ AMI Acute myocardial infarction \\ CT Computed tomography \\ EPC Endothelial progenitor cell \\ LV Left ventricular \\ SEM Standard error of the mean \\ SPECT Single photon emission computed tomography
}

\section{Introduction}

Cardiovascular disease remains a major cause of death and disability with its contribution to the world's burden of disease projected to rise [1]. Acute myocardial infarction (AMI) leads to irreversible myocardial fibrosis, and adverse left ventricular (LV) remodelling. Based on early reports from small animal models [2-6] there has been great interest for cell therapies to a) reduce myocardial 
injury and b) regenerate new myocardium. Endothelial progenitor cells (EPCs) have been shown to have potential in promoting cardiac repair through angiogenesis [7-10].

Early non-randomized clinical studies suggested beneficial effects on global LV function [11-13] although subsequent trials produced inconsistent results [14-17]. However, recent meta-analyses [18, 19] demonstrated significant, albeit modest, improvements in ejection fraction. Species differences in the absolute size of the infarcts and the nature and timing of the inflammatory response [20] may explain the variation in the degree of improvement between small animal and clinical studies. Amongst other factors, cell residence time has been shown to play an important role in influencing myocardial repair [21]. As well, direct intramyocardial delivery of cells has been explored for both endocardial (catheter based) and epicardial (full or mini-thorocotomy-based) injections with high and equivalent initial cell retention rates [22-25].

The current study was designed to determine the factors that affect cell residence time following direct injection, with infarcts comparable to patients in size and with a similar inflammatory response [20], with clinically applicable and validated imaging tools i.e. cell labelling (Indium-tropolone) and imaging (SPECT) [26, 27], and cell injection techniques (endocardial and epciardial). In this study, we examine cell clearance rates a) on the day of infarction, b) at 1 week and c) 4 weeks following the first injection, in two models of AMI; a sustained occlusion model, and a 2-h occlusion-reperfusion model.

\section{Methods}

\section{Cell preparation}

Autologous EPCs were isolated from the peripheral blood by density gradient centrifugation as described by He et al., and expanded to 30 million cells over 8 weeks, [28]. Cells were labeled with ${ }^{111}$ In-tropolone at $0.1 \mathrm{~Bq} / \mathrm{cell}$, a dose not affecting viability or proliferation [29].

\section{Surgical preparation}

Twenty-one 20-24 kg adult female bred-for-research hounds were used. All procedures were approved by the Animal Care Committee of the University of Western Ontario, and performed according to the Guide of the Animal Care and Use of Experimental Animals of the Canadian Council on Animal Care and Use of Laboratory Animals, National Research Council. The results from 14 of these animals, comparing cell retention and clearance rates for endocardial versus epicardial delivery, had previously been reported and the surgical methods described
[25]. Anesthesia was induced with propofol and maintained with isoflurane $(2 \%)$. Briefly, a myocardial infarction was induced by placing a snare ligature around the left anterior descending coronary artery distal to the first diagonal branch. In 11 animals, the snare was released $2 \mathrm{~h}$ following occlusion, and in the remaining 10 animals, the artery was tied off permanently. An additional 3 dogs, 2 with reperfusion, and 1 without, died suddenly within days following infarction, and their clearance times could not be measured.

\section{Timing of injection}

Eight animals received direct epicardial injections at thoracotomy, $4 \mathrm{~h}$ following occlusion. The remaining 13 animals received endocardial injections using a LV catheter. Seven of these endocardial injections occurred $4 \mathrm{~h}$ after the induction of the myocardial infarction and 6 occurred 1 week later. Eighteen animals received a second endocardial cell injection 4 weeks following the first injection i.e. at 4 or 5 weeks (Fig. 1), as 3 animals died in the interval period, one from congestive heart failure, and the other two from presumed fatal arrhythmias.

\section{Endocardial injections}

Endocardial injections used fluoroscopic guidance with the Stilletto ${ }^{\mathrm{TM}}$ Endomyocardial Injection System (Boston Scientific, Natick, MA) as previously described [25]. Briefly, biplane contrast ventriculograms were used to guide the injections into the myocardium, at the periphery of the wall motion abnormalities. Multiple injections (8-10) of $0.1 \mathrm{ml}$ each were delivered using a 26 -gauge needle.

Epicardial injections

At the time of the open thoracotomy, multiple injections (8-10) of $0.1 \mathrm{ml}$ were delivered into the peri-infarct region of the infarction, defined as the peripheral $1 \mathrm{~cm}$ of discoloration on the epicardial surface, using a 25 -gauge needle [25].

\section{SPECT/CT imaging and contrast-enhanced CT imaging}

Contrast enhanced CT was used to document the sites of injection in relationship to the zone of reduced perfusion. We have previously described the SPECT/CT imaging protocol in detail [25]. After background correction, the ${ }^{111}$ In projection data was reconstructed with three iterations of ordered subset expectation maximization. A volume of interest was defined on day 0 images corresponding to pixels with intensity $\geq 30 \%$ of the maximum pixel intensity. The number of counts in this volume at each followup was used to determine the mean pixel intensity 
Fig. 1 Timing of injectionEPCs labeled with ${ }^{111}$ Indium were injected by a subepicardial injection $(\mathrm{n}=8)$ on the day of infarction followed by subendocardial injection at 4 weeks, b subendocardial injection $(\mathrm{n}=7)$ on the day of infarction followed by subendocardial injection at 4 weeks, or c subendocardial injection at 1 week following infarction $(n=6)$ followed by subendocardial injection 4 weeks following the first. Follow-up SPECT/CT imaging occurred 4, 10, and 15 days after each cell transplantation. $E P C$ endothelial progenitor cell. $S P E C T / C T$ single photon emission computed tomography/computed tomography

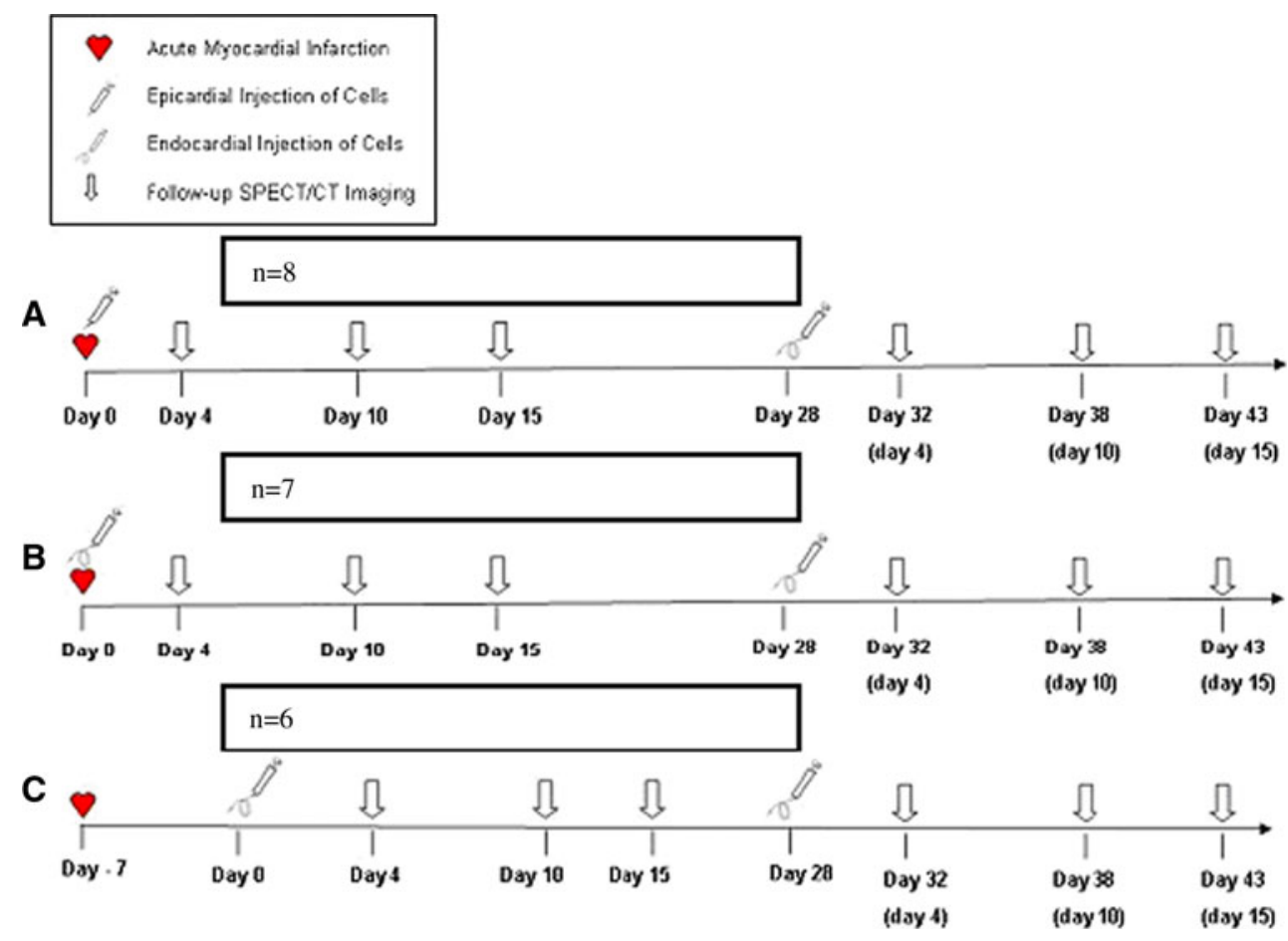

(MATLAB, Mathworks, Natick, MA). The mean pixel intensity in the day 4, 10 and 15 follow-ups were used to create in vivo time-activity curves of the ${ }^{111}$ In activity. They were decay corrected and fit to a monoexponential function in MATLAB and the half-life was reported in hours (Table 1).

\section{Statistical analysis}

Statistical analysis was performed using SPSS 17.0 (SPSS Inc., Chicago, IL). Comparison between injection techniques was performed using a univariate ANOVA. Comparison between sustained occlusion and reperfused models was performed using a 2-tailed independent samples $t$ test. Comparison between first and second injections in each animal was performed using paired sample t-tests. Statistical significance was set at a $P<0.05$ for all tests. All values are expressed as mean \pm SEM.

\section{Results}

In vitro ${ }^{111}$ In-tropolone labeling

In 39 cell labeling procedures, the average labeling efficiency was $77.1 \pm 1.5 \%$, resulting in an average dose of radioactivity delivered per cell of $0.1 \pm 0.003 \mathrm{~Bq} / \mathrm{cell}$.
Cell delivery efficiency

After each injection, the syringe and/or catheter used for the injection were evaluated for the amount of retained activity. For the first injection $8.4 \pm 1.3 \%$ of the activity remained in the syringe after the epicardial injections, while $15.7 \pm 2.1 \%$ of the activity remained in the syringe and catheter after the endocardial injections $(p=0.02)$.

The ratio of activity in the heart over the total activity in the body i.e. the myocardial retained activity, was similar between the epicardial $(56.7 \pm 6.0 \%)$ and endocardial $(59.5 \pm 5.5 \%)$ injections $(p=0.76)$.

\section{SPECT imaging}

\section{Epicardial versus endocardial injection (day 0) Table 1}

The clearance half-lives for cells injected into the epicardium were not significantly different from cells injected into the endocardium on the day of the infarction $(p=0.313)$.

\section{Endocardial injections: day 0 versus week 1}

The clearance half-lives of the cells injected into the endocardium on the day of infarction were similar to the clearance half-lives of cells injected into the endocardium 1 week after the infarction $(p=0.185)$. 
Table 1 Cell clearance half-lives of endothelial progenitor cells

\begin{tabular}{|c|c|c|c|}
\hline Canine & Model & $\begin{array}{l}\text { Injection } 1 \\
\text { Half-life (hours) }\end{array}$ & $\begin{array}{l}\text { Injection } 2 \\
\text { Half-life (hours) }\end{array}$ \\
\hline & & $\begin{array}{l}\text { Epicardial injection } \\
(\text { day } 0)\end{array}$ & $\begin{array}{l}\text { Endocardial injection } \\
\text { (week } 4)\end{array}$ \\
\hline 1 & $\mathrm{R}$ & 48.44 & 61.18 \\
\hline 2 & & 59.70 & 44.18 \\
\hline 3 & & 50.89 & 52.47 \\
\hline 4 & & 84.39 & 50.26 \\
\hline 5 & $S$ & 40.56 & 81.84 \\
\hline 6 & & 82.62 & 56.26 \\
\hline 7 & & 113.31 & $*$ \\
\hline \multirow[t]{3}{*}{8} & & 76.27 & 47.80 \\
\hline & & $69.5 \pm 8.5$ & $56.3 \pm 4.7$ \\
\hline & & $\begin{array}{l}\text { Endocardial injection } \\
\quad(\text { day } 0)\end{array}$ & \\
\hline 9 & $\mathrm{R}$ & 55.99 & 47.67 \\
\hline 10 & & 68.60 & 76.43 \\
\hline 11 & & 71.25 & 57.90 \\
\hline 12 & & 73.25 & 60.70 \\
\hline 13 & S & 83.62 & 66.33 \\
\hline 14 & & 90.16 & 74.27 \\
\hline \multirow[t]{3}{*}{15} & & 143.9 & 69.49 \\
\hline & & $83.8 \pm 10.8$ & $64.7 \pm 3.8$ \\
\hline & & $\begin{array}{l}\text { Endocardial injection } \\
\text { (week 1) }\end{array}$ & \\
\hline 16 & $\mathrm{R}$ & 42.11 & 69.25 \\
\hline 17 & & 40.49 & $*$ \\
\hline 18 & & 83.67 & 48.43 \\
\hline 19 & $\mathrm{~S}$ & 41.46 & $*$ \\
\hline 20 & & 90.50 & 96.16 \\
\hline \multirow[t]{2}{*}{21} & & 79.12 & 53.72 \\
\hline & & $62.9 \pm 9.5$ & $66.9 \pm 10.7$ \\
\hline
\end{tabular}

Values are mean \pm SEM

$R$ reperfused myocardial infarction, $S$ sustained occlusion myocardial infarction

* SPECT image not acquired

\section{Timing of injection (0-1 week vs. 4-5 weeks)}

All animals received two cell injections, the first either on the day of infarction or 1 week later, and the second 4 weeks following the first. Analysis was performed on the clearance half-lives between the first and second injection in each of the three categories of first injection (epicardial injection on day 0 , endocardial injection on day 0 and endocardial injection at week 1), and separately grouping all the early injections and comparing them to the late (4-5 week) injections. Although the clearance half lives comparing the smaller groups' early versus late injections did not approach statistical significance, when comparing all the early injections (Day 0 and Week 1) versus late injections, there was a trend towards a difference for the first $(\mathrm{n}=18, \quad 73.6 \pm 5.6 \mathrm{~h})$ versus second $\quad(\mathrm{n}=18$; $61.9 \pm 3.3 \mathrm{~h})$ injections $(p=0.074)$.

\section{Sustained occlusion versus reperfused tissue}

A comparison between sustained occlusion $(\mathrm{n}=10)$ and reperfused $(\mathrm{n}=11)$ models for injection 1 revealed that the cell clearance half-lives of $84.2 \pm 9.6$ and $61.6 \pm 4.7 \mathrm{~h}$, for the occlusion and reperfused models respectively, were significantly different $(p=0.042)$, but no significant difference for injection $2,68.2 \pm 5.0 \mathrm{~h}$ versus $55.5 \pm 3.3 \mathrm{~h} \quad(p=0.086) \quad$ (Table 2$)$. However, when grouping all the sustained occlusion versus all the reperfused injections, there was a significant difference for sustained occlusion $77.1 \pm 6.05(\mathrm{n}=18)$ versus reperfused $59.4 \pm 2.9 \mathrm{~h}(\mathrm{n}=21), p=0.009$.

\section{Contrast enhanced CT}

The post-contrast enhanced cardiac SPECT/CT showed areas of hypo-perfusion in all animals indicating low blood flow. All injections were localized within the zone of reduced contrast towards the periphery of this zone (Fig. 2).

\section{Discussion}

Our study is the first to assess some of the factors that affect cell residence time in a large animal model of myocardial infarction. We have shown that endocardial and epicardial injections have similar residence times and may direct further research towards endocardial injections as they are technically easier to perform clinically, although safety issues may be a concern. Regarding the other tissue based parameters, previous large animal studies tracked cells under a single condition, i.e. single time of injection or sustained occlusion/reperfusion, but not both, which is unique to our study. Our laboratory has previously validated the technique of Indium tropolone labeling [26, 27], for quantitative measurement of cell clearance. There are

Table 2 Mean cell clearance half lives of endothelial progenitor cells in sustained occlusion and reperfused models of myocardial infarction

\begin{tabular}{llll}
\hline $\mathrm{n}$ & Model & $\begin{array}{l}\text { Injection 1 } \\
\text { Half-life (hours) }\end{array}$ & $\begin{array}{l}\text { Injection 2 } \\
\text { Half-life (hours) }\end{array}$ \\
\hline 11 & $\mathrm{R}$ & $61.6 \pm 4.7^{\mathrm{a}}$ & $55.5 \pm 3.3$ \\
10 & $\mathrm{~S}$ & $84.2 \pm 9.6$ & $68.2 \pm 5.0$ \\
\hline
\end{tabular}

Values are mean \pm SEM

$R$ reperfused myocardial infarction, $S$ sustained occlusion myocardial infarction, $n$ sample size

${ }^{\mathrm{a}} \mathrm{R}$ versus $\mathrm{S} p=0.042$ 

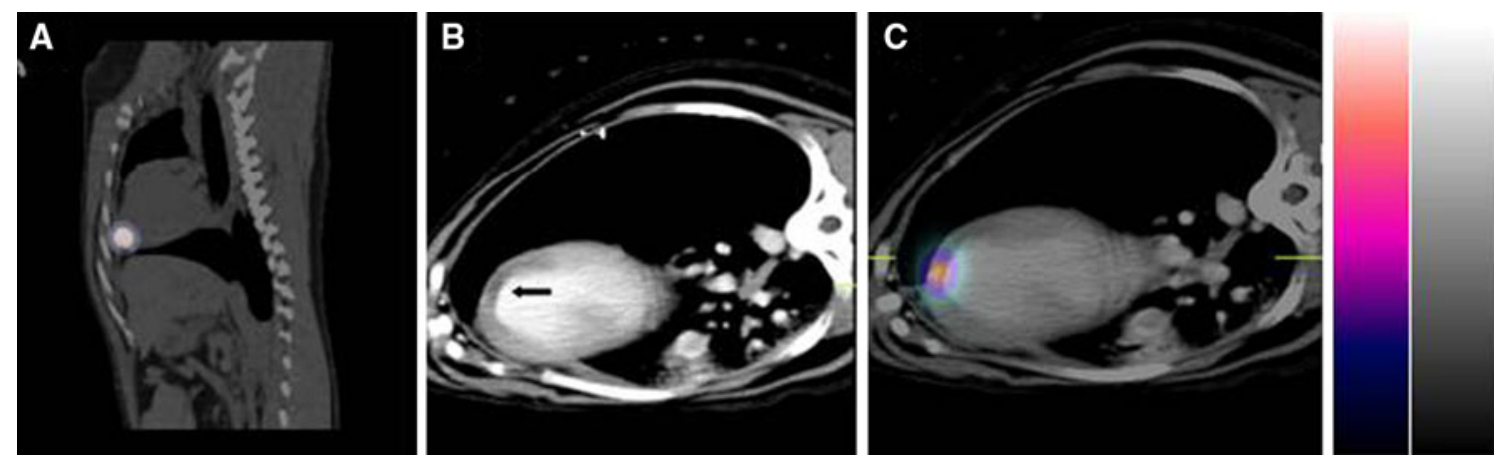

Fig. 2 SPECT/CT - day 0 imaging of ${ }^{111}$ Indium labeled EPCs transplanted in a canine heart by endocardial injection a Coronal fused SPECT/CT image showing activity localized to the heart. b Transaxial contrast-enhanced CT image with arrow denoting hypo-

other methods to track cells following transplantation [3039], some of which have demonstrated approximately the same range of clearance half-times seen in our study [38].

However, the status of the tissue, and cell type appear to have a significant bearing on clearance rates, based on work in a rat model using optical imaging [40]. Longer clearance times for stromal cells were found if they were (a) injected at 30 min versus 5 days, (b) transplanted into normal versus infarcted myocardium, (c) syngeneic transplants versus allogeneic and (d) treated with immunosuppressive therapy.

Also, the time of injection appears to have an effect as Schachinger reported that cell retention declined as the time elapsed since the infarct increased [41] in a clinical study of patients ranging from 5 days to 17 years.

\section{Endocardial injections: day 0 versus week 1}

Macrophage invasion in canine myocardial infarction has a slow sustained progression starting at $24 \mathrm{~h}$, and peaking at 7 days [20]. In our study, the endocardial injections on day 0 occurred $4-5 \mathrm{~h}$ after coronary occlusion, before the major infiltration of macrophages, whereas the injection at 1 week occurred at its peak. Had the radioactive debris from dead transplanted cells been engulfed by the resident macrophages, we would have observed an apparent prolonged cell clearance at 1 week. However, we found similar clearance half-lives at day 0 and week 1 arguing against this hypothesis.

\section{Timing of injection (0-1 weeks vs. 4 weeks)}

Each animal received two cell injections, separated by 4 weeks, with a trend towards longer half-lives with the earlier injections. This may have been related to lower blood flows initially with a gradual increase over time related to augmented collateral supply. However, we did not measure regional myocardial perfusion to validate this enhanced region within the infarction, $\mathbf{c}$ Transaxial contrast-enhanced CT image fused with SPECT image of transplanted EPCs. EPC endothelial progenitor cell, SPECT/CT single photon emission computed tomography/computed tomography

hypothesis. In theory, earlier cell injections may be more beneficial in limiting the full evolution of an infarct, but this is also unproven. Further, providing an adequate number of cells to culture expand and then transplant for early injections at 1 week would be problematic, and their safety remains a concern.

\section{Sustained occlusion versus reperfused tissue}

The residence time following transplantation into the sustained animals was longer by $17.7 \mathrm{~h}$ on average compared to reperfused animals. This difference would produce approximately twice as many cells still resident at the site of infarction at 10 days after injection (1/8th vs. 1/16th). If treatment effect is correlated with cell residence times, this would suggest that greater myocardial regeneration would occur, everything else being equal. However, we did not assess the extent of infarction or alternatively, the viability of the infarcted/ischemic tissue in this study to make this direct link.

\section{Variation in cell clearance}

These may be related to differences in infarct size, variations in collateral flow around the coronary artery occlusion, in basal heart rate, and blood pressure between animals. Also, the injections were targeted solely based on wall motion abnormalities, which could be caused by stunned, hibernating, or infarcted myocardium (viability status was not used to direct the injections). The contrast enhanced CT images confirmed that, in all cases, the injections had been placed within the zone of reduced perfusion, and generally towards its periphery.

\section{Safety and clinical relevance}

Here, we have shown that careful experiments using a large animal model (canine) were undertaken with a relatively 
low overall attrition rate of $6 / 24(25 \%)$, primarily from arrhythmias, which is consistent with our experience over the past 25 years with this model. There were no perforations. Gyongyosi has reported on the safety of early post infarction injections in 60 patients receiving direct myocardial injections at either 3-6 weeks or 3-4 months 42], and Krause demonstrated the safety of direct endocardial injections an average of 10.5 days after infarction [43], with no peri-procedural complications. We have shown here that late injections at 4-5 weeks are associated with comparable cell clearance as for injections within the first week.

\section{Study limitations}

The focus of this study was to determine if clinically significant differences in transplanted cell residency time were a function of infarct status (reperfused vs. chronic), time of injection after infarct event or route of cell administration (epicardial vs. endocardial). Hence protocol design was optimized to achieve these results with a minimum number of dogs. This was achieved by injecting each animal twice (day 0 or 1 week followed by a second injection 4 weeks after the first). This allowed post hoc analysis with paired sample t-testing for increased statistical power for the same number of animals but also introduced study limitations. Treatment effect could not be investigated as 4 weeks is, in our experience [44], too short a time after the first injection to assess this. Additionally, with two injections, any treatment effect at a remote time point e.g. 12 weeks could not be uniquely attributable to one of the two injections. Another concern is the potential contaminating effect of any residual treatment response or inflammatory reaction, of the first injection on the 4-5 week residence times. However, on review of the data, (Table 1), there was no consistent pattern seen from first to second injection. The relatively small sample sizes in each group limited the size of the effects that can be seen with statistical certainty. For example we would have needed much larger sample sizes (27-62 animals/group based on Cohen's effect size for two independent means, $p<0.05$, power $=0.80$ ) to have demonstrated that the differences between injection 1 and injection 2 were significant or the differences between the epicardial versus endocardial injections were different. However the aim of the study was to determine if differences were large and hence would likely have an impact in clinical application and this, we argue, was achieved.

\section{Conclusions}

The transplanted cell clearance kinetics injected on the day of infarction, at 1 week and 4-5 weeks following infarction showed no statistical difference, although there was a trend to longer half-lives for the earlier injections.

Sustained occlusion infarcts, which generally are larger than reperfused ones, and would benefit most from regeneration, had statistically longer cell retention times. Although it is beyond the scope of this article to discuss in detail, the current clinical trial evidence suggests no prognostic benefit to delayed re-opening of a chronically occluded coronary artery [45]. If cell residence time is associated with treatment effect size and/or transplanted cell proliferation, relatively greater effects would be observed following transplantation into the peri-infarct region of sustained occlusion infarcts.

Acknowledgments We thank Michelle Belton, Astrid ChamsonReig and Donna Goldhawk for assistance with cell culture, Yves Bureau for statistical analysis and Janice DeMoor for assistance in manuscript preparation. Financial support for this project was received from the Heart and Stroke Foundation of Ontario, Toronto, Ontario, the Canadian Institutes for Health Research, Ottawa, Ontario and the Ontario Ministry of Research and Innovation. We also acknowledge the support of Boston Scientific, Natick, Massachusetts who provided the Stilletto catheters.

\section{Conflict of interest None.}

Open Access This article is distributed under the terms of the Creative Commons Attribution License which permits any use, distribution, and reproduction in any medium, provided the original author(s) and the source are credited.

\section{References}

1. Bloom BR (2005) Public health in transition. Sci Am 293:92-99

2. Kamihata $H$, Matsubara $H$, Nishiue T, Fujiyama $S$, Tsutsumi $Y$, Ozono R, Masaki H, Mori Y, Iba O, Tateishi E, Kosaki A, Shintani S, Murohara T, Imaizumi T, Iwasaka T (2001) Implantation of bone marrow mononuclear cells into ischemic myocardium enhances collateral perfusion and regional function via side supply of angioblasts, angiogenic ligands, and cytokines. Circulation 104:1046-1052

3. Kudo M, Wang YG, Wani MA, Xu MF, Ayub A, Ashraf M (2003) Implantation of bone marrow stem cells reduces the infarction and fibrosis in ischemic mouse heart. J Mol Cell Cardiol 35:1113-1119

4. Makino S, Fukuda K, Miyoshi S, Konishi F, Kodama H, Pan J, Sano M, Takahashi T, Hori S, Abe H, Hata J, Umezawa A, Ogawa S (1999) Cardiomyocytes can be generated from marrow stromal cells in vitro. J Clin Invest 103:697-705

5. Nishida M, Li TS, Hirata K, Yano M, Matsuzaki M, Hamano K (2003) Improvement of cardiac function by bone marrow cell implantation in a rat hypoperfusion heart model. Ann Thorac Surg 75:768-773

6. Orlic D, Kajstura J, Chimenti S, Jakoniuk I, Anderson SM, Li B, Pickel J, McKay R, Nadal-Ginard B, Bodine DM, Leri A, Anversa $\mathrm{P}$ (2001) Bone marrow cells regenerate infarcted myocardium. Nature 410:701-705

7. Asahara T, Murohara T, Sullivan A, Silver M, van der Zee R, Li T, Witzenbichler B, Schatterman G, Isner JM (1997) Isolation of putative progenitor endothelial cells for angiogenesis. Science 275:964-967 
8. Badorff C, Brandes RP, Popp R, Rupp S, Urbich C, Aicher A, Fleming I, Busse R, Zeiher AM, Dimmeler S (2003) Transdifferentiation of blood-derived human adult endothelial progenitor cells into functionally active cardiomyocytes. Circulation 107: 1024-1032

9. Kawamoto A, Gwon HC, Iwaguro H, Yamaguchi JI, Uchida S, Masuda H, Silver M, Ma H, Kearney M, Isner JM, Asahara T (2001) Therapeutic potential of ex vivo expanded endothelial progenitor cells for myocardial ischemia. Circulation 103: 634-637

10. Kawamoto A, Tkebuchava T, Yamaguchi JI, Nishimura H, Yoon YS, Milliken C, Uchida S, Masuo O, Iwaguro H, Ma H, Hanley A, Silver M, Kearney M, Losordo DW, Isner JM, Asahara T (2003) Intramyocardial transplantation of autologous endothelial progenitor cells for therapeutic neovascularization of myocardial ischemia. Circulation 107:461-468

11. Assmus B, Schächinger V, Teupe C, Britten M, Lehmann R, Dobert N, Grunwald F, Aicher A, Urbich C, Martin H, Hoelzer D, Dimmeler S, Zeiher AM (2002) Transplantation of progenitor cells and regeneration enhancement in acute myocardial infarction-(TOPCARE-AMI). Circulation 106:3009-3017

12. Britten MB, Abolmaali ND, Assmus B, Lehmann R, Honold J, Schmitt J, Vogl TJ, Martin H, Schächinger V, Dimmeler S, Zeiher AM (2003) Transplantation of progenitor cells and regeneration enhancement in acute myocardial infarction (TOPCARE-AMI): mechanistic insights from serial contrast-enhanced magnetic resonance imaging. Circulation 108:2212-2218

13. Schächinger V, Assmus B, Britten MB, Honold J, Lehmann R, Teupe C, Abolmaali ND, Vogl TJ, Hofmann WK, Martin H, Dimmeler S, Zeiher AM (2004) Transplantation of progenitor cells and regeneration enhancement in acute myocardial infarction-final one-year results of the TOPCARE-AMI trial. J Am Coll Cardiol 44:1690-1699

14. Meyer GP, Wollert KC, Lotz J, Pirr J, Rager U, Lippolt P, Hahn A, Fichtner S, Schaefer A, Arseniev L, Ganser A, Drexler H (2008) Intracoronary bone marrow cell transfer after myocardial infarction: 5-year follow-up of the BOOST trial. Circulation 118:S764-S765

15. Meyer GP, Wollert KC, Lotz J, Steffens J, Lippolt P, Fichtner S, Hecker H, Schaefer A, Arseniev L, Hertenstein B, Ganser A, Drexler H (2006) Intracoronary bone marrow cell transfer after myocardial infarction-eighteen months' follow-up data from the randomized, controlled BOOST (BOne marrOw transfer to enhance ST-elevation infarct regeneration) trial. Circulation 113:1287-1294

16. Wollert KC, Meyer GP, Menke A, Arseniev L, Hertenstein B, Ganser A, Knapp WH, Drexler H (2005) Monitoring of bone marrow cell homing to the infarcted human myocardium. Circulation 111:2198-2202

17. Yousef M, Schannwell CM, Koestering M, Zeus T, Brehm M, Strauer BE (2009) The BALANCE study: clinical benefit and long-term outcome after intracoronary autologous bone marrow cell transplantation in patients with acute myocardial infarction. J Am Coll Cardiol 53:2262-2269

18. Martin-Rendon E, Brunskill SJ, Hyde CJ, Stanworth SJ, Mathur A, Watt SM (2008) Autologous bone marrow stem cells to treat acute myocardial infarction: a systematic review. Eur Heart J 29:1807-1818

19. Wen Y, Meng L, Xie J, Ouyang J (2011) Direct autologous bone marrow-derived stem cell transplantation for ischemic heart disease: a meta-analysis. Expert Opin Biol Ther 11:559-567

20. Dewald O, Ren GF, Duerr GD, Zoerlein M, Klemm C, Gersch C, Tincey S, Michael LH, Entman ML, Frangogiannis NG (2004) Of mice and dogs: species-specific differences in the inflammatory response following myocardial infarction. Am J Pathol 164: $665-677$
21. Ziebart T, Yoon C, Trepels T, Wietelmann A, Braun T, Kiessling F, Stein S, Grez M, Ihling C, Muhly-Reinholz M, Carmona G, Urbich C, Zeiher AM, Dimmeler S (2008) Sustained persistence of transplanted proangiogenic cells contributes to neovascularization and cardiac function after ischemia. Circ Res 103:1200-1201

22. Freyman T, Polin G, Osman H, Crary J, Lu M, Cheng L, Palasis M, Wilensky RL (2006) A quantitative, randomized study evaluating three methods of mesenchymal stem cell delivery following myocardial infarction. Eur Heart J 27:1114-1122

23. Hale SL, Dai W, Dow JS, Kloner RA (2008) Mesenchymal stem cell administration at coronary artery reperfusion in the rat by two delivery routes: a quantitative assessment. Life Sci 83:511-515

24. Hou D, Youssef EAS, Brinton TJ, Zhang P, Rogers P, Price ET, Yeung AC, Johnstone BH, Yock PG, March KL (2005) Radiolabeled cell distribution after intramyocardial, intracoronary, and interstitial retrograde coronary venous delivery implications for current clinical trials. Circulation 112:1150-1156

25. Mitchell AJ, Sabondjian E, Sykes J, Deans L, Zhu W, Lu X, Feng Q, Prato FS, Wisenberg G (2010) Comparison of initial cell retention and clearance kinetics after subendocardial or subepicardial injections of endothelial progenitor cells in a canine myocardial infarction model. J Nucl Med 51:413-417

26. Blackwood KJ, Lewden B, Wells GR, Sykes J, Stodilka RZ, Wisenberg G, Prato FS (2009) In vivo SPECT quantification of transplanted cell survival after engraftment using ${ }^{111}$ In-tropolone in infarcted canine myocardium. J Nucl Med 50:927-935

27. Blackwood KJ, Sykes J, Deans L, Wisenberg G, Prato FS (2011) Comparison of leakage from labeled endocardial and epicardial cells: impact on modeling viability of cells to be transplanted into myocardium. Int J Mol Imag 2011:472375

28. He HB, Shirota T, Yasui H, Matsuda T (2003) Canine endothelial progenitor cell-lined hybrid vascular graft with nonthrombogenic potential. J Thoracic Cardiovasc Surg 126:455-464

29. Blackwood KJ, Mitchell AJ, Zhu W, Feng Q, Goldhawk D, Dhanvantari S, Wisenberg G, Prato FS (2009) Evaluation of dose-dependent effects of ${ }^{111}$ In on canine endothelial progenitor cells for cell tracking. Eur J Nuc Med Mol Imag 36:S239

30. Hofmann M, Wollert KC, Meyer GP, Menke A, Arseniev L, Hertenstein B, Ganser A, Knapp WH, Drexler H (2005) Monitoring of bone marrow cell homing into the infarcted human myocardium. Circulation 111:2198-2202

31. Graham JJ, Foltz WD, Vaags AK, Ward MR, Yang Y, Connelly KA, Vijayaraghavan R, Detsky JS, Hough MR, Stewart DJ, Wright GA, Dick AJ (2010) Long-term tracking of bone marrow progenitor cells following intracoronary injection post-myocardial infarction in swine using MRI. Am J Physiol Heart Circ Physiol 299:H125-H133

32. Kim YJ, Huh YM, Choe KO, Choi B, Choi E, Jang Y, Lee J, Suh JS (2009) In vivo magnetic resonance imaging of injected mesenchymal stem cells in rat myocardial infarction; simultaneous cell tracking and left ventricular function measurement. Int $\mathrm{J}$ Cardiovasc Imaging 25:99-109

33. Kraitchman DL, Heldman AW, Atalar E, Amado LC, Martin BJ, Pittenger MF, Hare JM, Bulte JW (2003) In vivo magnetic resonance imaging of mesenchymal stem cells in myocardial infarction. Circulation 107:2290-2293

34. Amsalem Y, Mardor Y, Feinberg MS, Landa N, Miller L, Daniels D, Ocherashvilli A, Holbova R, Yosef O, Barbash IM, Leor J (2007) Iron-oxide labeling and outcome of transplanted mesenchymal stem cells in the infarcted myocardium. Circulation 116:I38-I45

35. Chen IY, Greve JM, Gheysens O, Willmann JK, RodriguezPorcel M, Chu P, Sheikh AY, Faranesh AZ, Paulmurugan R, Yang PC, Wu JC, Gambhir SS (2009) Comparison of optical bioluminescence reporter gene and superparamagnetic iron oxide MR contrast agent as cell markers for noninvasive imaging of cardiac cell transplantation. Mol Imag Biol 11:178-187 
36. Higuchi T, Anton M, Dumler K (2009) Combined reporter gene PET and iron oxide MRI for monitoring survival and localization of transplanted cells in the rat heart. J Nucl Med 50:1088-1094

37. Blackwood KJ, Kong H, Stodilka RZ, Sykes J, Wisenberg G, Prato FS (2006) In vivo evaluation of thymidine kinase overexpression to track canine bone marrow stromal cells using dual isotope SPECT. Mol Imag 5:234

38. Gyöngyösi M, Blanco J, Marian T, Trón L, Petneházy O, Petrasi Z, Hemetsberger R, Rodriguez J, Font G, Pavo IJ, Kertész I, Balkay L, Pavo N, Posa A, Emri M, Galuska L, Kraitchman DL, Wojta J, Huber K, Glogar D (2008) Serial noninvasive in vivo positron emission tomographic tracking of percutaneously intramyocardially injected autologous porcine mesenchymal stem cells modified for transgene reporter gene expression. Circ Cardiovasc Imag 1:94-103

39. Stodilka RZ, Blackwood KJ, Prato FS (2006) Tracking transplanted cells using dual-radionuclide SPECT. Phys Med Biol 51:2619-2632

40. Westrich J, Yaeger P, He C, Stewart J, Chen R, Seleznik G, Larson S, Wentworth B, O'Callaghan M, Wadsworth S, Akita G, Molnar G (2010) Factors affecting residence time of mesenchymal stromal cells (MSC) injected into the myocardium. Cell Transplant 19:937-948

41. Schächinger V, Aicher A, Döbert N, Röver R, Diener J, Fichtlscherer S, Assmus B, Seeger FH, Menzel C, Brenner W, Dimmeler S, Zeiher AM (2008) Pilot trial on determinants of progenitor cell recruitment to the infarcted human myocardium. Circulation 118:1425-1432
42. Gyöngyösi M, Lang I, Dettke M, Beran G, Graf S, Sochor H, Nyolczas N, Charwat S, Hemetsberger R, Christ G, Edes I, Balogh L, Krause KT, Jaquet K, Kuck KH, Benedek I, Hintea T, Kiss R, Preda I, Kotevski V, Pejkov H, Zamini S, Khorsand A, Sodeck G, Kaider A, Maurer G, Glogar D (2009) Combined delivery approach of bone marrow mononuclear stem cells early and late after myocardial infarction: the MYSTAR prospective, randomized study. Nat Clin Pract Cardiovasc Med 6:70-81

43. Krause K, Jaquet K, Schneider C, Haupt S, Liozonov MV, Otte KM, Kuck KH (2009) Percutaneous intramyocardial stem cell injection in patients with acute myocardial infarction: first-inman study. Heart 95:1145-1152

44. Wisenberg G, Lekx K, Zabel P, Kong H, Mann R, Zeman PR, Datta S, Culshaw CN, Merrifield P, Bureau Y, Wells G, Sykes J, Prato FS (2009) Autologous myocardial stem cell therapy in a canine model of myocardial infarction: a multi modality approach to stem cell tracking and therapy evaluation of bone marrow monocytes and stromal cells using SPECT and MRI. J Cardiovasc Magn Reson 11:11

45. Hochman JS, Lamas GA, Buller CE, Dzavik V, Reynolds HR, Abramsky SJ, Forman S, Ruzyllo W, Maggioni AP, White H, Sadowski Z, Carvalho AC, Rankin JM, Renkin JP, Steg PG, Mascette AM, Sopko G, Pfisterer ME, Leor J, Fridrich V, Mark DB, Knatterud GL (2006) Occluded artery trial investigators. Coronary intervention for persistent occlusion after myocardial infarction. N Engl J Med 355:2395-2407 